\title{
SOCIETY AFFAIRS
}

OFFICERS OF RESEARCH STANDING COMMITTEES, 1947

\section{Farm Woodlot:}

Chairman-I. C. Marritt, Ontario Forest Branch, Dept. of Lands E Forests, Galt, Ont.

Secretary-(To be Appointed).

Forest Entomology:

Chairman-R. E. Balch, Furest Entomologist, Dept. of Agriculture, Fredericton, N.B.

Secretary-Dr. M. L. Prebble, Box 975, Forest Insect Laboratory, Sault Ste. Marie, Ont.

\section{Forest Fire:}

Chairman-H. W. Beall, Dominion Forest Service, Dept. of Mines and Resources, Ottawa, Ont.

Secretary-J. R. Johnston, Fire Control Officer, B.C. Forest Service, Dept. of Lands EF Forests, Victoria, B.C.

Forest Pathology:

Chairman-Dr. J. E. Bier, Dept. of Botany, University of Toronto, Toronto, Ont.

Secretary-C. G. Riley, Central Experimental Farm, Ottawa, Ont.

\section{Reforestation:}

Chairman-H. G. McWilliams, B.C. Forest Service, Dept. of Lands and Forests, Victoria, B.C.

Secretary-G. A. Mulloy, Dominion Forest Service, Dept. of Mines E Resources, Ottawa, Ont.

\section{Silviculture:}

Chairman-A. P. MacBean, c/o H. R. MacMillan Export Co. Ltd., Parksville, B.C.

Secretary-to be appointed.

Surveys:

Chairman-H. E. Seely, Dominion Forest Service, Dept. of Mines E? Resources, Ottawa, Ont.

Secretary-W. R. Grinnell, Ontario Forest Branch, Dept. of Lands \& Forests, Toronto, Ont.

\section{Wood Utilization:}

Chairman--T. A. McElhanney, Forest Products Laboratories, Dept. of Mines $E^{2}$ Resources, Ottawa, Ont.

Secretary-E. S. Fellows, Ottawa, Ont. 
SOCIETY AFFAIRS

\title{
NEWS OF THE SECTIONS
}

\section{MARITIMES}

\section{A Recommendation That Is Already Giving Results ${ }^{1}$}

\author{
By R. H. Burgess,
}

Maritime Forest Ranger School, Fredericton, New Brunswick

Prior to 1935 representatives of Provincial Forest Services and private forest organizations inquired if the University of New Brunswick could give a short course in forestry to train young active men engaged in the forest as rangers, wardens, scalers, lookout men, timekeepers and foremen. These men provide the backbone of the whole body of forest labour, and the course required would be designed primarily to train them in skills necessary in their work, and in up-to-date methods and operations consistent with good forestry practice. It was felt that one of the difficulties that hinders the proper practice of forestry in the Maritimes was the lack of trained forest labor. Foresters with four or more years of college training are competent to prepare the plans of management, but the forester is charged with the administration of very large areas, often hundreds of thousands of acres of forest land, and these plans in the past have been carried out by men entirely unfamiliar and often out of sympathy with the aims and practices of forest conservation.

In all it was estimated that a capital investment of a quarter of a million dollars and an annual expenditure of twenty-five thousand would be required to finance the proposed School, and in those days the lumber industry was not in any too prosperous a condition, and it was feared that the public would not accept the long-term view necessary to justify the large expenditure.

With the war came increased demands for forest products and increased exploitation. All concerned now realized the need for trained supervisors if our forest wealth was to be preserved.

In January, 1944, the New Brunswick Forest Products Association and the New Brunswick Section of the Canadian Forestry Association presented a brief on "Forestry and Post-War Reconstruction in New Brunswick" to the New Brunswick Committee on Reconstruction. One of their recommendations was that "The University of New Brunswick establish a School for technical instruction of men for forest services and forest industries. This must be done in time to provide key men for post-war projects."

The Woodlands Managers of the three largest pulp and paper companies in the Province, the Provincial Forester of Nova Scotia, and Senator F. W. Pirie, then Minister of Lands $\&$ Mines, New Brunswick, also indicated the need for this type of training and promised the support of their respective organizations.

\footnotetext{
1This is Section Note No. 2 published by the Maritime Section, C.S.F.E.
} 
The staff of the University Forest School then drew up a "memorandum concerning a Ranger School", which the President presented to the University Senate for their approval. The main points emphasized were: "A Ranger School is basically a School where secondary education can be presented to train men in forest protection, supervision of cutting operations, scaling, surveying and similar subjects, so that they may be employed as fire wardens, forest rangers, scalers, camp clerks, inspectors and cruisers. It corresponds to training non-commissioned offcers in the army. To build up a sound Forestry program, it is necessary to have in woods organizations men who have a sympathetic understanding of the needs of Forestry, in addition to a knowledge of specific duties for various types of forest work. This purpose can be accomplished through a Ranger School.

"There is a definite place in industrial and governmental service for men with this type of forestry training, men who can work with less supervision from foresters, and who may develop into foremen and supervisors of woods work. There should be no conflict between the graduate forester and the Ranger School man. Their contributions are complementary. A more effective use of men, materials and the forest resources would follow the introduction of both professionally and technically trained personnel. The members of the Faculty of the University of New Brunswick Forest School, therefore, recommend that a Ranger School be established at the University of New Brunswick."

The University Senate concurred in the project and asked that plans be developed so as to make the School of the utmost value.

Invitations were sent to representatives of the Provincial Governments of New Brunswick and Nova Scotia and the forestry industries throughout the two provinces to attend a conference in connection with the establishment of the School.

Everyone present agreed on one thing, the urgent need for men with technical training in forest work. It was decided that the School could only be a success if it had the full support of industry. The graduate must be absorbed in the industry, and if the demand for men with Ranger School training was to be fully developed, the training given would have to follow the lines of a trade school, and the course kept adjusted to fit the needs of industry. Members of industry also stressed the fact that at the present time they had no means of training the men themselves, and preferred to assist a central school rather than organize a training program of their own.

A sub-committee was formed to work out the necessary details for the School. This Committee reported as follows: "The proposed School would provide basic traniing for (a) Forest Rangers; (b) Scalers; (c) Timber Cruisers; (d) Logging Inspectors; (e) Camp Clerks. Various special short courses might also be arranged in such subjects as: (a) operation and care of mechanical equipment; (b) saw-mill operation; (c) lumber grading; (d) cooking; etc. The regular course would consist of four terms of two months each, spread over a period of two years. 
Among other things the Committee proposed that a fund be set up to provide for capital cost and operating costs during the first several years of operation. This fund was to be made up of equal contributions by Government and industry.

The New Brunswick Government immediately put $\$ 100,000$ at the disposal of the authorities vested with the responsibility of organizing the School. The Nova Scotia Government followed with a contribution of $\$ 50,000$.

The University, in co-operation with the Governments of New Bruns. wick and Nova Scotia, decided to proceed with the establishment of the School.

Three Committees were formed to draw up final arrangements.

The Ranger School was now a reality. Work went forward and details were worked out to supplement the broad outline of plans drawn up by the Committee.

A 70-acre property, adjacent to the University Forest, was purchased for a building site, and on November 8, 1945, construction of the School buildings was started. The main plant consists of a dormitory, administration building, workshop, garage and sawmill.

The University Forest is operated as a unit to supply raw material to the School plant, and the students are able to get practical instruction in all phases of the operation from planting and securing reproduction to grading of manufactured products.

In all field work on scaling, cruising, logging, milling and other subjects approved, up-to-date methods are used, and training is such that the student with a good woods background is capable of doing these various jobs on completion of the course without any apprenticeship in the industry.

Shortly after the University decided to go ahead with the School representatives of some of the larger pulp and paper companies in the Maritimes said that their companies were so interested in the establishment of the Ranger School that they were willing to contribute toward the cost of the School and were only too glad to assist the students by giving them work between terms, with the understanding that those suitable would be given full-time employment on completion of the course.

The New Brunswick International Paper Company made a contribution of $\$ 25,000$, Fraser Companies $\$ 25,000$, the Bathurst Power $छ$ Paper Company $\$ 15,000$, and the Mersey Paper Company Limited $\$ 10,000$.

The brief that was presented to the New Brunswick Committee on Reconstruction stressed the point that training should start as soon as possible to provide key men on post-war projects, so it was decided to run the School in the army quarters at Alexander College until the Ranger School buildings were completed.

The first class of fifty students, made up of 48 veterans and 2 nonveterans, started on April 1, 1946. 
These students took the following subjects during their first term (2 months) at the School: Forest Law, Mathematics, Forest Measurement, Sur veying, Drafting, Botany, and Forest Fire Prevention and Control.

The mornings were used for lectures in the classroom, and the afternoons were spent in field work on the college woodlot. Of the fifty stu. dents that started the course, forty-seven completed the first two months successfully, and left for their four months field term.

During the students' four months' field term, a record is kept by their employer and is sent to the School before the student returns for his second two months' term. This employment report tells of the number of days the student is employed at the following types of work: Operations (logging, stream driving, milling); scaling; counting; cut inspection; timber cruising; surveying; forest fire protection (actual experience on fires, towers, etc.); construction (camps, bridges, dams, towers, telephone lines, roads, etc.); mechanized equipment (automobiles, trucks, tractors, fire-pumps, motors, boats, etc.); time-keeping; bookkeeping; clerking and checking. This report also tells us the student's attitude toward work, his sense of responsibility, his ability and whether the employer considers the student suitable for further training.

Of the forty-seven students who left the School for their four months' field term all returned, or are intending to return, for their second two months' term, except five. One of these is now preparing himself for a University course, and the other four have given up their course.

A break-down of the first class, showing the number of students em. ployed in the different phases of forestry work, is as follows: Miramichi Survey-9; Fire-fighting, pumps, etc.--11; Cruising-10; Scaling-1; Survey-3; Clerking-2; Tree-working for selection cut--1; Road location \& construction-4; and cut location - 1 . A student did not necessarily work at fire-fighting or cruising for four months steady, but that was the particular job at which he spent most of his four months. Of these forty-two students six received fair reports, and three received poor reports. The remaining students received good reports on their work.

No. 2 Class is now back at the School taking its second two months' term. Reports received of their field work were very satisfactory.

No. 3 Class is at present out on their first four months period of field work.

Summing up, it would appear that the recommendation put forward by the New Brunswick Forest Products Association and the New Brunswick Section of the Canadian Forestry Association to the New Brunswick Committee on Reconstruction regarding the establishment of a School for technical instruction of men for forest services and forest industries was a sound one, and that it is now giving results even at this early stage.

Personalia

Dr. W. R. Haddow while vacationing in Cape Breton took time out to discuss forestry with members of the Maritime Section. 
George Tunstell of the Dominion Forest Service made his first official visit to the Maritimes. While here he attended the Annual Meeting of the Registered Foresters at Nictau.

I. C. M. Place, who spent the summer on a regeneration survey in Nova Scotia and New Brunswick returns to Yale this month.

Harris Videto spent the summer with the Resources Development Board of New Brunswick and now leaves for England on a Beaverbrook Overseas Scholarship.

R. C. Parent, an Agriculturalist who did much to promote woodlot management amongst New Brunswick farmers has been appointed Superintendent of the Experimental Farm, Charlottetown.

Prince Edward Island is a fruitful field for farm woodlot work and $\mathrm{Mr}$. Parent will have a greater opportunity of promoting better woodlot management and soil conservation-his two pet projects.

All Dominion Forest Service parties will have completed their summer work by Sept. 15. Work has been done on management plans, regeneration, fire hazard, farm woodlot management. (We understand that Mr. Veness is still looking for an Assistant at the Maritime District Office.)

Members of the New. Brunswick Forest Service staff have been instructed to collect 2,600 bushels of seed. These will be used in reseeding burnt over Crown Land.

Douglas Long has returned to the Maritimes and will teach Silviculture and Dendrology at the U.N.B. Forest School.

Drs. Spaulding and Hansborough of the U.S. Department of Agriculture visited Nova Scotia to examine the work done by $L$. S. Hawbold and Dr. Skolko in respect to the dieback of birch. Investigations are being carried out in Nova Scotia to see if an excavation of the roots of birch trees will give any further clue to the cause of this dieback.

MeEtings

The Eighth Annual Meeting of the Maritime Lumber Bureau was held at the Maritime Forest Ranger School.

Chairman J. D. Hickman gave a brief description of the lumber situation in the Maritimes, some of the present trends and what the policy of the Maritime Lumber Bureau should be to meet the future. John Bigelow, Secretary. Manager, in his annual report stated the aims and outlined the development of the Maritime Lumber Bureau.

More than 100 people attended the luncheon tendered by Hon. R. J. Gill, New Brunswick Minister of Lands and Mines. The luncheon speakers were Hon. E. T. Kenny, Minister of Lands and Mines for British Columbia, Hon. J. H. Mc2uarrie, Minister of Lands and Forests for Nova Scotia, and W. E. Uren, Canadian Timber Controller. During the regular meeting, R. G. MacFarlane of Fraser Companies gave a most interesting report on his recent trip to Scandinavia.

The Registered Foresters of New Brunswick held their annual meeting at Nictau Lake on the 6th, 7th and 8th of August. Committees were set up as follows:-Education Committee, T. M. Pond, Chairman; D. E. Nickerson 
and A. T. Pelletier, members. Purpose-to sell better forestry practice to the public. Forest Fire Committee, L. S. Webb, Chairman; John Ferris and D. A. Wolstenholm, members. Purpose-methods of detecting and supressing forest fires. Colonization Committee, J. C. Veness, Chairman; V. C. Bastin and W. W. McCormack, members. Purpose-to ascertain that forest land is suitable for agriculture before it is denuded of its trees. Surveys Committee, Kaare Smith, Chairman; K. B. Brown and P. M. Harrison, members. Purpose-Progress and techniques in inventory and map making, using aerial photographs. Forest Motor Roads Committee-J. M. Gibson, Chairman; H. H. Hoyt, and E. G. Saunders, members. Purpose - to determine what methods would accelerate the development of a more adequate system of forest roads in New Brunswick.

R. E. Balch has just returned from the Fifth British Empire Forestry Conference. The papers he presented at the Conference were "Forest Entomology in Canada" and "Forests and Forestry in New Brunswick".

One reason for the Conference was to determine what supplies of wood were available within the Empire and the part Canada could play in meeting the present wood shortage.

The following topics were also amongst the subjects discussed:- the relationship between forestry and agriculture in land utilization; the need for increased forest protection; the need for long term management plans; the need for forest products research.

The Maritime Retail Lumber Dealers met Aug. 30 and 31 at St. Andrews, New Brunswick. The President, R. S. Chappell of Sydney, Nova Scotia, forecast a 3-year building boom for the Maritimes provided certain essential building supplies, notably lumber, became available in greater quantities.

Province of Quebec

The summer meeting of the Province of Quebec Section, C.S.F.E., was held at the Forest Ranger School, Duchesnay, Quebec, August 19 and 20. Those who attended were-R. Bellefeuille, R. Delisle, Ellwood Wilson, G. C. Piché, Andre Linteau, Dr. A. R. Gobeil, J. Frenette, C. H. Bernier, M. Gerin, P. Amyot, Omer Lussier, G. L. Breton, J. A. Audette, B. A. Logan, and K. G. Fensom. G. C. Piché acted as chairman.

The meeting was largely devoted to a discussion of farm woodlots. This discussion was led by R. Delisle, who is in charge of extension foresters of the Department of Lands and Forests, and who presented an interesting paper-"Small and Medium Scale Privately Owned Woodlands in the Province of Quebec."

\section{OtTawa Valley}

Reminiscences $^{1}$

By W. M. ROBERTSON

It is with regret that I relinquish the chairmanship of the Ottawa Valley Section of the Canadian Society of Forest Engineers. A few days ago I submitted my resignation as secretary of the Silvicultural Committee. few days hence I will be retired from the Dominion Forest Service.

1W. M. Robertson recently retired as Chief of the Silvicultural Division, Dominion Forest Service and as Chairman of the Ottawa Valley Section, C.S.F.E. 
The consistently high attendance at the Section's meetings during the year suggests that some progress has been made, despite the difficulty in locating a suitable meeting room. For the solution of this problem we are deeply indebted to the E. B. Eddy Company for placing their recreation hall at our disposal. We are indebted, too, to the various speakers who gave of their time to prepare and deliver their addresses. I am glad to be able to report about 25 per cent increase in our membership.

Any success we may have had has been made possible only by the support of the members, the co-operation of your executive council, and in particular by the untiring efforts of your secretary.

Ever since the distribution of the work of the Society under a series of Committees in 1935 it has been my privilege to act as secretary or chairman of the Silvicultural Committee whether or not our 'efforts were worthwhile may be determined from a perusal of the annual reports on record.

It remains for others to say what use I have made of my one, two or five talents during my thirty years of post-graduate work in the field of silvicultural research.

May I 'reminisce' awhile-with the aid of notes from Defebaugh's History of the Lumber Industry in America.

Those of you who have attempted to keep a daily diary realize how little there seems to be to record. Even annual reports record comparatively little progress. But a review of developments by decades shows quite a different picture.

Reared in a Georgian Bay lumbering village I have been associated with forest industry in one phase or another for six decades.

I have seen the first major forest industry in Eastern Canada die an unnatural death; the second rise and fall; the third rise, quaver and revive. Today several new industries are coming into being.

Dates ending in seven have been red letter days for me. In 1887 I started school - an event which I then thought to be a calamity. School days ended on February 3, 1897, when our home was burned. My mother was buried on February 3, 1907. I spent February 3, 1917, in hospital. On February 3, 1927, our complete research program was upset in favour of a stock taking survey. Six weeks of 1937 were spent on sick leave. On February 3, 1947, I received notice to vacate my desk-out into the cold cold world on my donkey in the snow. The history of forest industries in Ontario seems to be likewise ear-marked.

"In $1807 \mathrm{Mr}$. (Philemon) Wright took the first raft of square timber down the Ottawa to Quebec ${ }^{1 "}$. This may therefore be considered the beginning of the first major forest industry in Ontario and western Quebec.

Twenty years later Wright started operations in the neighborhood of By-Town. That year the Rideau Canal was started. Peter Robinson was appointed surveyor general of woods and forests for Upper Canada, and the first returns from timber licences, $\$ 360$, were received.

Disputes over timber licences were one cause of the Mackenzie rebellion of 1837.

1Defebaugh, E. History of the Lumber Industry of America. 
"The modern lumbering system as contrasted with the old fashioned method of conducting the industry may be said to have commenced during the 50's" 1 . This decade may therefore be considered to be the beginning of the white pine sawmill industry. Mills of J. R. Booth, E. B. Eddy, Bronson and Weston, Perley and Puttee and many others date from 1857.

Confederation of Canada in 1867 greatly stimulated the two industries.

With sale of extensive timber limits in the Algonquin region in 1872 . 77 great expansion resulted, and the square timber industry af proached its climax.

By 1887 Canadian lumbermen became perturbed about the export of sawlogs to Michigan mills.

But it was not until 1897 that an Act was passed by the Ontario Legislature requiring that all logs cut on crown lands be manufactured in Canada. This Act resulted in the stimulation of sawmill development and the decline of the square timber industry.

By 1903 there were no fewer than 46 large sawmills in the Ottawa Valley and Georgian Bay. That year Booth's mill alone cut 115 million board feet of pine, probably a million feet a day for the sawing season. The total output of lumber for 1904 was 1,737,000,00 board feet. That year witnessed the end of the square timber business.

As late as 1901 the Minister of Public Works considered that, without regrowth and reforestation, the supply was sufficient to last for 150 years. How wrong he was is evidenced by the rapid decline of the saw timber industry commencing in 1907.

The total output of all mills remaining in 1927 was less than that of the Booth mill alone in 1903.

Of the 46 thriving mills in 1903 but two remain today, those of Gillies Bros., at Braeside, and the Pembroke Mills at Pembroke. Thus the second industry had come to a close.

The first record of pulpwood cutting was in 1891 when 864 cords were made. By 1897 the cut had increased to 46,000 cords. It was not until 1907 that the output for Canada amounted to a million cords which might be considered as the commencement of the changeover in woods operations. In 1917 the cut was three million cords; by 1927 it had doubled to six million cords. The years 1931 to 1935 witnessed a considerable depres sion and decline in output. In 1937 it had increased to over 8 million cords at which point it oscillated during the war years.

Today new industries using heretofore unused species are springing into being, so that our only weed species are black alder and hazel. Splint. wood, plywood, veneer, masonite, poles and small products industries are clamoring for birch, maple, poplar, basswood and jack pine.

Thus history has proved that if Canada's primary resource is to be maintained we must practise forestry. 'It is becoming more and more apparent that industrial organizations are beginning to realize this truth, and in this thought there is hope for the future. 


\section{PraIRIe Provinces}

Oscar G. Larsson of the Dominion Forest Service at Calgary has accepted a position with the Abitibi Power and Paper Company at Island Falls, On. tario. Mr. and Mrs. Larsson carry with them the best wishes of Alberta foresters. He takes over his new duties on the first of September.

Lawrence A. deGrace, also of the Dominion Forest Service, Calgary, leaves early in September to take a post-graduate course in forestry at the University of California.

We note that Herbert $A$. deVeber was one of the speakers at the dedication of the peace cairns on the international boundary in the WatertonGlacier International Peace Park.

Recent visitors to the Kananaskis Forest Experiment Station include Messrs. R. H. Candy and H. W. Beall of the Dominion Forest Service, Ottawa; Maj.-Gen. Howard Kennedy, C.B.E., M.C., of Ottawa, Chairman of the Eastern Rocky Mountain Forest Conservation Board; E. W. Bassett, Chief of the Forest Protection Division of the British Columbia Department of Lands and Forests; J. R. Johnston, Fire Control Officer, also of the B.C. Department of Lands and Forests; R. R. Lejeune, Officer-inCharge, Dominion Entomological Laboratory, Winnipeg; and Dr. Helge Johnson, of the Swedish Institute of Tree Breeding.

\section{NEWS OF THE ADVERTISERS}

"Drench"-New Fire-Fighting Tool, Now Available in Canada

Woodsmen everywhere will rejoice to know that they have a new and powerful ally in their fire-fighting efforts. This is a recently discovered chemical product known as "Drench", a small proportion of which, added to water, increases water's fire-fighting effectiveness by many times.

The facts are little short of astonishing. "Drench" is actually a wetting agent; its ability to make water wetter has been used for years by textile mills to enable bleaching or dyeing solutions to penetrate fabrics thoroughly and evenly. That's how Arnold, Hoffman EO Co., Inc., long a supplier of chemicals to the textile industry, got interested in wetter water for fires.

Their interest was intensified also by the fact that E. H. Arnold, presi. dent of Arnold, Hoffman, Co., Inc., was appointed to the Governor's Fire Study Committee after the big destructive Rhode Island forest fire of 1942.

Wet water is not new to chemists, nor to the textile industry. Ask the chemists and they'll tell you that a wetting agent increases saturating action of water by reducing the surface tension which keeps it in compact globules.

You can take an eyedropper and try it out. If you squeeze out a drop of water on a piece of paper it'll remain in a droplet. The same thing may happen when you spray it on a fire. 1This is an advertising news release inserted as a courtesy service to Watson Jack \& Co.
Ltd., Montreal, Que. 